\title{
Against All Odds? The Enduring Value of Liberal Education in Universities, Professions, and the Labour Market*
}

\author{
PAUL AXELROD, PAUL ANISEF, \& ZENG LIN \\ York University, York University \& Illinois State University
}

\begin{abstract}
The humanities, the social sciences and the fine arts - the core subjects of liberal education - are at risk in Canadian universities, and the danger arises largely from the forced reorientation of higher education to assumed market needs. This paper attempts to explain why such policy shifts are occurring; it points to the continuing cultural, social and intellectual value of liberal education; and, drawing from recent and previously unreported census data, it demonstrates that liberal education produces generally positive economic benefits to the individual graduate. It concludes that policies designed to diminish the presence of liberal education in universities in favour of more supposedly "market-worthy" subjects are short-sighted and threatening to the integrity and vitality of higher education.
\end{abstract}

* This is a revised version of a paper Anisef, Axelrod, and Lin (1999) presented to the conference, "Trade Unions and Training: from Global Demands to Local Action" Université Laval, May 29, 1999. The conference was sponsored by the Labour Education and Training Research Network which is administered by York University's Centre for Research on Work on Society. The Network also provided research support for this paper. 


\section{RÉSUMÉ}

Les lettres, les sciences sociales et les arts - les domaines d'étude formant le noyau dur de l'éducation libérale - sont à risque dans les universités canadiennes, et le danger vient principalement de la réorganisation forcée de l'éducation supérieure pour répondre aux demandes du marché. Cet article tente d'expliquer pourquoi ces changements de politique se produisent; il s'intéresse à la valeur culturelle, sociale et intellectuelle de l'éducation libérale; et, s'inspirant des données de récents recensements et d'autres précédemment effectués, il démontre que l'éducation libérale produit généralement des avantages économiques chez ses gradués. Cet article conclut que les politiques servant à diminuer la présence de l'éducation libérale dans les universités à la faveur de programmes soit disant plus valables pour le marché sont à courte vue et menace l'intégrité et la vitalité de l'éducation supérieure.

\section{INTRODUCTION}

The humanities, the social sciences and the fine arts - the core subjects of liberal education - are at risk in Canadian universities, and the danger arises largely from the forced reorientation of higher education to assumed market needs. This paper attempts to explain why such policy shifts are occurring; it points to the continuing cultural, social and intellectual value of liberal education; and, drawing from recent and previously unreported census data, it demonstrates that liberal education produces generally positive economic benefits to the individual graduate. It concludes that policies designed to diminish the presence of liberal education in universities in favour of more supposedly "market-worthy" subjects are short-sighted and threatening to the integrity and vitality of higher education. 


\section{THE CONTEXT OF CHANGE}

Universities have struggled in the past, but as Paul Axelrod (1998) has observed:

recent funding cuts appear to have been accompanied by an apparent sea of change in public policy. The principle of ample public funding to relatively autonomous universities, which enabled a diverse academic curricula - including the liberal arts - to grow and thrive, is in question. The doctrines of globalization, privatization, institutional competition, market-driven programming, and user-pay fee schedules are now pushing at the gates of higher learning. (pp. 6-7)

Policy makers and business leaders now tend to favour what Sheila Slaughter and Larry Leslie (1997) call "academic capitalism" As Kjell Rubenson (1977) notes, the policy focus increasingly is on the "exchange value" of education. In this world students pay a far higher portion of university costs, corporations play a growing role in shaping university policy, university funding is tied more and more to graduate employment "outcomes," research support from the public and private sector is driven increasingly by business and high technology needs, and faculty entrepreneurialism and private universities are fostered. (See also Tudiver, 1999; Wilson, 1999).

For Peter Godsoe (1996), CEO of Scotiabank, these types of polices are both desirable and inevitable:

Our university system will see a period of rationalization over the next decade; overlapping programs must be eliminated or merged, and greater efficiencies in program delivery and in administration will have to be found and developed... We need to unbundle our funding and allow universities to compete for research grants; we need to tolerate variation in tuition fees to promote institutional excellence; and we need to permit private institutions to play a role in our university system. Let the market, not the government, determine which universities succeed and where our centres of excellence are. (pp. 42, 45). 
In late 1997, Premier Mike Harris of Ontario questioned the "surplus" number of university programs in fields such as geography and sociology, and in March 2000, his government introduced a "performance indicator" system which ties a portion of a university's funding to the employment experiences of university graduates, a practice pioneered several years earlier in Alberta (Mallen \& Rushowy, 2000). In addition, in the previous month, Ontario announced a construction programme for the province's universities ( $50 \%$ of which is expected to be funded by the private sector) which is almost entirely oriented to applied sciences, business and technology, and "away from the humanities and social sciences" (Ibbitson, 2000).

Why should anyone be concerned about these trends? Isn't the attempt to reap higher investments from a more efficient university system economically rational and politically defensible? If students are unlikely to obtain good jobs when they graduate, shouldn't they be discouraged from enrolling in those programs that appear to offer substandard employment prospects? Shouldn't funding be directed away from the humanities, the social sciences and the fine arts to more market-worthy programs such as business, computer science, engineering, and various high technology programs? We question these assumptions and conclusions, and argue that not only do the liberal arts pay off, but that their demise would damage Canadian social and intellectual life.

\section{WHAT IS LIBERAL EDUCATION?}

The concept of liberal education is filled with paradox. It is at once the most enduring and changeable of academic traditions. It owes its origins to the philosophers and teaching practices of Ancient Greece and, arguably, continues to embrace certain core values from that era. According to Vanderleest (1996), these include the development of the whole person, the cultivation of character and citizenship, and the achievement in learning and living of balance and harmony (see also, Rothblatt, 1993). But there have been, and remain, different approaches to achieving these ends. While some liberal educators have stressed a "classical philosophic tradition" which steeps the student in ancient and 
biblical texts, others have embraced the "humanistic" perspective, which, largely through literature, exposes readers to the breadth of human experience and accomplishment, seeking, thereby to "fit" the individual for "freedom" Yet another facet of liberal education is that which employs the "scientific method" through which research specialists are trained to discover new knowledge. Finally, the "twentieth century pragmatic vision" encourages students to treat all claims to truth skeptically, to problem-solve, and to attempt to make education an instrument of social change and the social good (Glyer \& Weeks, 1998; Rothblatt, 1993).

Bruce A. Kimball (1995) characterizes the ongoing debate among liberal educators as one which pits "philosophers" against "orators." The former believe that "the pursuit of knowledge is the highest good" (p. xvii), and that truth itself is mutable. The latter contend that the primary goal of the university is to teach that which is known, and to instill in students the skills required to express such enduring truths.

Most recently, the Association of American Colleges and Universities (1999) offered this rather ecumenical conception of liberal learning:

A truly liberal education is one that prepares us to live responsible, productive, and creative lives in a dramatically changing world. It is an education that fosters a well grounded intellectual resilience, a disposition toward lifelong learning, and an acceptance of responsibility for the ethical consequences of our ideas and actions... Because liberal learning aims to free us from the constraints of ignorance, sectarianism, and shortsightedness, it prizes curiosity and seeks to expand the boundaries of human knowledge. By its nature, therefore, liberal learning is global and pluralistic. It embraces the diversity of ideas and experiences that characterize the social, natural and intellectual world... (pp. 6-7).

One could add that, ideally, liberal educators require students to demonstrate the ability to think analytically, to question received wisdom, to express themselves clearly (orally and in writing), to apply different perspectives and theories to a text or real life situations, and to cultivate one's own philosophy and sense of values (see also Schneider \& Shoenberg, 1998). As James O. Freedman (1996) contends, liberal 
education should "help students to develop an independent perspective for reflecting on the nature and the texture of their lives... More [than anything] it conveys to students a sense of joy in the learning - a joy in participating in the life of the mind." (p. 2).

Conceptions of liberal education, then, run the risk of being contradictory or exceedingly broad, and the literature is rife with generalizations and platitudes. Still, we believe that a meaningful definition of liberal education is possible, both for the purposes of this paper, and for purposes of curriculum development in higher education. Our definition attempts to reflect the traditions and dynamism of liberal education, and its continuing pertinence to society. Liberal education in the university refers to activities which are designed to cultivate intellectual creativity, autonomy and resilience; critical thinking; a combination of intellectual breadth and specialized knowledge; the comprehension and tolerance of diverse ideas and experiences; informed participation in community life, and effective communication skills. These goals are usually pursued in the humanities, social sciences, and fine arts (generally deemed the "liberal arts"), but as we argue below, they can and should be integrated into scientific, technical and professional education.

The notion of cultivating "intellectual creativity," "autonomy" and "resilience" links conceptions of liberal education from the past and present. Liberal education should enable individuals (students and professors alike) to expand their intellectual horizons and to continue that process outside formal educational experiences. "Autonomy," a more contemporary goal, encourages the student and the professional researcher to engage in scholarship that is unconstrained by external authority. This, indeed, is the foundation of academic freedom. Dogmatism in the classroom, or dictation of research outcomes by supervisors or sponsors, have no place in the university. Similarly, "critical thinking" underlines the value of questioning received wisdom on the basis, not merely of instinct or opinion, but of informed analysis and understanding.

Requiring a combination of "intellectual breadth and specialized knowledge" attempts to bridge different understandings of the university's role. Recalling the mid-nineteenth century educational philosophy of Cardinal Newman, proponents of traditional forms of liberal education 
see specialized studies as fragmenting and narrowing academic life, and denying students a coherent, integrated body of knowledge (Wagner, 1998). Those who favour specialized study point to the continuous explosion of knowledge in the arts and sciences; in depth study of at least one subject gives students valuable experience in exploring the literature of a discipline from which original ideas and research flow (Little, 1998). Without offering any specific curricular formulation, we believe that general education and specialized study have a central place in university life, and that the liberally educated require exposure to both.

Cultivating "tolerance of diverse ideas and experiences" is perhaps the most current concept that we believe ought to be integral to the ideals of liberal education. In positing this principle, we reject the notion that a single, universal body (or canon) of thought can be successfully imposed upon a university curriculum. Throughout history, the curriculum has evolved, in part at least, in response to newer constituencies of students. For example, the spread of professional education in the late nineteenth and early twentieth centuries reflected the interests of middle class families in preparing youth for secure and prestigious employment (Axelrod, 1990; Bledstein, 1976). The growing presence in higher education of female students, particularly since the 1960 s, and of cultural and racial minorities, has been accompanied by the new fields of women's studies and multicultural studies. Controversy has frequently followed the integration of these subjects into the curriculum, but we believe that the scholarly diversity they have generated has enriched academic life. At the same time, much remains to be gained from the continuing study of classical western texts and philosophies. Hence, the need for open-mindedness and "tolerance" if university life is to be conducted civily, and if liberal education is to thrive.

The notion of preparing young people for their role as citizens reaches back to ancient times. In the modern era, echoing the work of John Dewey, liberal education is often linked to the cultivation of "democratic" values (Simpson \& Jackson, 1997). We agree with this sentiment, but we prefer the somewhat broader concept of "informed participation in community life." Communities consist of citizens and non-citizens, and of constituencies whose definitions of democracy vary. 
The important point is that the liberally-educated ought to be willing and able to contribute to the enrichment of the communities which they inhabit. Liberal education should serve to connect, not to isolate, academic and community life.

Should liberal education foster "communication skills?" Despite the technical tone of this goal, we believe that all academics are, or should be, engaged in this task. Thinking originally, researching creatively, writing clearly and speaking persuasively intrinsically reward the individual and serve him or her well in the world beyond the university

We have defined the goals of liberal education in these ways because we believe they draw from the best of traditional and contemporary academic values, reflecting both the enduring characteristics and dynamic nature of liberal education itself. Notwithstanding the debates that such discussions will invariably stimulate, we believe that university courses in the arts, sciences and professions should be mounted and assessed in light of their ability to achieve these aims.

\section{SCIENTIFIC, TECHNICAL AND PROFESSIONAL EDUCATION}

While liberal educators have been known to disagree profoundly with each other, all would likely concur that an educational approach which focuses exclusively on technical training is sorely lacking. As Charles W. Anderson (1993) argues, "a principal aim of teaching is to bring students to see the pattern behind the great structured systems of rational inquiry" (p. 186). Much technical knowledge, after all, has a limited life span. Consider, for example, the fate of computer programmers in the 1970s who believed that their knowledge of the COBOL and FORTR'AN programming systems would secure their positions in the industry for the foreseeable future. These systems, however, were quickly superseded by new programming methods some of which in turn became all but obsolete (Armstrong \& Casement 1998; McPherson \& Schapiro, 1999). Those who assume that higher education is merely about dealing with "known problems in known ways," and who therefore lack the intellectual resilience to learn new skills, cope with uncertainty, or even change fields are potential casualties in the world of 
employment (Lipman-Blumen, 1995). In encouraging students to question received wisdom and to probe such topics the relationship between technology and social change, liberal education can effectively broaden the perspectives of engineering, computer science, and other technicallyminded students.

Though they are not always heeded by company recruitment officers, corporation CEOs have periodically called for the hiring of those trained in the liberal arts over the narrowly qualified business school graduate. As far back as 1959, the president of Imperial Oil praised liberal education for broadening students' intellectual horizons, thereby making them especially valuable in the workforce. "Industry has found that it can train an educated man [sic] but it cannot necessarily educate the trained man [sic]" (Axelrod, 1982, p. 107). Leap to the 1990s, and Matthew Barrett, former president of the Bank of Montreal, contends that:

[It] is far more important that students graduate from university having read Dante, or the great historians of today and yesterday, then understanding the practice of double-entry accounting... Education should impart fact, not training, not even skills above essential literary and numeracy, but rather the "cross-curriculum" abilities to reason, to imagine, to think laterally, and perhaps most important, to welcome learning as an essential part of life. (Frank, 1997, p. 8)

This point is underlined by author, Don Tapscott (1999), an enthusiastic proponent of the "digital" universe. He contends that there is a significant shortage of skilled technology professionals in Canada, and that universities must expand their enrolments in fields such as engineering and computer science. But he insists that:

the digital economy will also demand graduates of a liberal arts and sciences education. Their education makes them flexible and adaptable and gives them a valuable breadth of knowledge, and bolsters their ability to think and analyze. And most important of all, it gives them the ability to continue to learn throughout life. (p. C3)

Business students trained narrowly in operational techniques will, in all likelihood, proved less successful than those commerce graduates 
who have some understanding of social psychology, community dynamics, or cultural life in the countries in which companies invest knowledge gained through liberal arts education. As Michael Useem (1995) notes, business practitioners who understand foreign languages and a community's environmental concerns bring breadth and added value to their workplaces that the less educated lack. Furthermore, Jeffrey Nesteruk (1999), a business ethics teacher argues that business teaching which ignores the principle that "all knowledge is rooted in self-knowledge" is constraining and potentially harmful. Self-knowledge, he contends:

is a necessary component in the changing role of business managers. As functions more traditionally public become privatized, the general public looks to effective executives as social leaders. To successfully adapt to this changing role requires those in business to regard themselves in new ways, to be self-evaluative - and this depends significantly on the foundation of well-developed habits of introspection." Ethical issues, from "whistle-blowing" to "product safety" compel business persons to "wrestle with their own standards of right and wrong, their self conceptions and character, and their perceptions of their roles in complex commercial" - again, issues central to liberal education. (p. 57)

Such concerns may well explain why chief executive officers in a major American survey on the benefits of a college education had a broader perspective on the value of higher learning than did parents and college-bound students. The latter two groups focussed mostly on the short-term outcome of "getting a job," while the former considered, far more frequently, the long-term benefits of higher education. As Hersh (1997) noted, employers in the survey were presumably no less practically-minded than parents and students.

But to them practicality means the ability of higher education to impact general skills that give people the flexibility and capacity to keep learning what today's high-tech businesses require... They insist that a college education produce people of strong character with generalized intellectual and social skills and a capacity for learning. (p. 188) 
The particular facilities that human resource managers valued were three-fold: cognitive (problem-solving, critical thinking, and learning to learn), presentational (oral and written communication skills) and social (working cooperatively in a variety of settings).

Innovations in the medical education field well illustrate the ways in which liberal studies, academic science, and clinical training can be effectively combined to improve the quality of medical practice. Traditionally, medical students have been steeped in a narrow, scientific educational process that concentrates on the "disease and not the patient" Complaints in the 1930s that "the specialist looks too frequently upon the problem of the patient solely from the aspect of his specialty, rather than from the needs of the patient as a whole" (Rappleye, 1932, p. 24) were echoed in 1999 by a professor of clinical surgery at Yale who claimed that faculty members have been rewarded more for specialized research than "for teaching well, or for caring for (or even about) patients" (Nuland, 1999, p. 124).

New initiatives in medical education, however, now focus on issues central to the social sciences (Schmidt, 1990). Perhaps the most innovative such program is the internationally renown McMaster Medical School in Hamilton, Ontario. Founded in 1965, McMaster employed admission procedures and pedagogy that departed dramatically from the practices of traditional medical schools. While the latter have compelled applicants to have a strong background in the biological sciences, and to excel on the Medical College Admission Test, McMaster has not required these, nor has it privileged candidates with high grades. Instead, students with backgrounds in the humanities and social sciences, those with varied experiences and interests, and those committed to groupbased, problem-solving learning strategies, are more likely to be admitted. In addition, recruitment committees, which include current medical students, engage short-listed applicants in personal interviews (unlike most medical schools).

Throughout the medical training program, McMaster students meet in small groups led by a faculty tutor.

Various aspects of a health problem - ranging from the basic science concepts needed to understand the Patho physiology, 
through the impact on the patient and the family - are identified by group members who seek out the appropriate learning resources in order to acquire the knowledge with which to manage the problem. The basic and clinical sciences are presented in an integrative manner, rather than individually. The learning approach emphasizes the student as an active learner and places more responsibility for their education on students. Lectures, called large-group resource sessions, are few and are optional for the student. About $20 \%$ of the program is devoted to student-selected electives. (Woodward, 1990, pp. 27-28)

The program encourages and seeks to improve upon the "life-long learning habits of physicians" (Woodward, 1990, pp. 27-28). Surveyed regularly, McMaster students have consistently praised this active form of instruction.

In order to compare its graduates with those elsewhere, McMaster closely monitored the performance and careers of its students between 1976 and 1980. In their first post-graduate year, supervisors found no differences between the performance of McMaster and non-McMaster graduates, nor were there observable differences between those with a science and non-science background. Thus, students trained in the arts proved, ultimately, to be as adept in the technical practice of medicine as their scientifically-oriented colleagues. However, career patterns did vary. A survey of all McMaster graduates from 1972 to 1979 (75\% response rate) used two comparison groups, one matched with McMaster graduates only by year of graduation, and another by year of graduation, gender and age. The results showed that McMaster produced more physicians who went into teaching, research and administration, i.e. academic medicine, than any other medical school in Canada (Woodward, 1990). While it is possible that some McMaster alumni were oriented to teaching before they entered medical school, it seems likely that the school's alternative admission and pedagogical practices have played a significant role in turning out different kinds of graduates than have traditional schools. Notably, the medical school at Sherbrooke University in Quebec, which also employs independent study and problem-based learning, has graduated, according to McPhedran (1993), "socially 
conscious general practitioners." In the province's Local Community Services Centre units located in "underserviced" communities, "half the positions are filled with Sherbrooke graduates... The educational program has stimulated other French universities, in Canada and abroad, to review and modify their curricula" (McPhedran, 1993, p. 207).

Another medical school initiative flowed from a resolution at the World Summit on Medical Education in 1993 which called upon medical education to become more "community oriented" to focus students' attention on "real world settings," and to encourage them to "respond to the needs of society" (Wasylenki et al., 1997). This led to a new course, now compulsory for University of Toronto medical students, called "Health, Illness and the Community." The course requires students in first and second year to spend one half-day per week working in placements that involve some 300 community agencies and to explore the issues arising from their experiences. Students first observe patients in their residences in order to understand better how "people cope with illness and disability in the home environment." They then spend time at a public health unit where they are exposed to such issues as "domestic violence, sexually transmitted diseases and smoking cessation." This is followed by a section in the course on "health determinants and health promotion strategies," and includes two agency placements which address these themes. In their second year, students focus on the "interconnection between a health problem and a social issue." Coordination between community agencies and teaching hospitals enable students to grapple directly with the medical and social elements of the issues they are investigating. Throughout the two-year course, students are exposed to a variety of readings from social science fields.

The program has been assessed positively by students, patients and agencies. Students especially appreciate the field placements, though as Wasylenki et al (1997). note, "the course is weaker on the theoretical side, because an integrating conceptual model has not yet been developed" (pp. 382-383). Improving the course thus requires a more effective melding of the academic and hands-on empirical practical approaches. Even in its early phase, the course has demonstrated the potential value of a training program that combines social and medical 
science, and the virtue of grappling with health problems within a social context. Whether it will actually produce physicians who employ more holistic, community-based forms of medical practice remains to be seen.

According to research conducted by the Consultative Group on Research and Education in Law concluded, Canadian law schools, notwithstanding their applied educational functions, perceive themselves to be offering legal education that is both humane and professional rather than narrowly vocational. Ideally, the emphasis is on cultivating in students a profound understanding of the law as a social phenomenon and an intellectual enterprise. Law schools generally identify three elements as characteristic of this type of legal education:

- learning legal rules (what we will call "doctrine," recognizing the somewhat different common law and civil law connotations of the term) and developing the ability to use the rules;

- learning legal skills (such as interviewing, advocacy and negotiation);

- developing a humane perspective on law, and a deeper understanding of law as a social phenomenon and an intellectual discipline (Consultative Group on Research, 1983, p. 55).

To underline the importance of the links between liberal education and legal practice, a number of universities do offer legal studies within their arts faculties. Carleton University is the largest of these though similar programs also exist at Waterloo, Regina, York, Brock, and elsewhere (Consultative Group on Research, 1983). Notwithstanding these initiatives, the new political economy that now threatens liberal education has affected law students. Arthurs (1998) contends that:

they are increasingly impatient, as a group, with "humane professionalism," the ethos of Canadian law schools since the 1960 s, and they increasingly avoid "purely academic" offerings. And this brings them into direct conflict with their already beleaguered professors, who confront heavier work loads, more rigorous performance measures, declining financial prospects - and now, its seems likely, intellectual frustration. (p. 31) 
Thus, Tagg (1998) speaks of the need to move from a conventional instruction to a learning paradigm:

Changing the governing paradigm, becoming learning-driven institutions, may seem a daunting task for today's knowledge factories. It seems a little like asking the post office to become a church. Yet the reason that the ideal of liberal education survives in our cultural imagination is that it addresses an ongoing need, the need to nurture in the young the development of both heart and mind, the need to set young people on a course that offers not just facility but maturity, not just cleverness but wisdom. (p. 292)

Similarly, Michael Higgins, the President of St. Jerome's College at the University of Waterloo, contends that the classical aims of liberal education have relevance, perhaps more than ever, in contemporary society:

The pressure [today] is on the cultivation of those skills that are marketable. You don't want somebody coming out [of university] with a degree in Aristotelian metaphysics. But in an important way, the people who are the metaphysicians or the epistemologists or the specialists in old English, are... precisely the ones we want to be educated for the future. They're the ones we want to be able to make discerning judgements, to understand the past, to be discriminating, to understand the implications of things that are not visible and palpable and tangible and immediate, things that are not driven by the kind of ephemeral mystique we associate with the media, but who are, in important ways, able to dissect and to analyze. In many ways, the traditional humanities, philosophy, English, literature studies did precisely that. (Canadian Broadcasting Corporation, 1999, p. 158)

\section{LIBERAL EDUCATION AND THE COMMUNITY}

As well as cultivating "general habits of mind which will pay off in good performance when applied to any constructive endeavor" (Anderson, 1993), liberal education, according to Bond (1982), can effectively serve 
the democratic processes if students obtain a critical understanding of how society gathers, processes and communicates information:

When a new Secretary of State makes a policy statement on human rights, "There will be no de-emphasis but a change in priority," we can see past the vigor and self-confidence and know that he is talking nonsense, that he knows he is talking nonsense, and that he assumes that we will not know the difference. These are important things for us to know. (p. 140)

Using both academic and "experiential" modes of teaching, universities should - better than they do now - contribute to enlightened citizenship, community participation, and, in the process help an "information society" become a more "informed society" (van der Zee, 1996).

Nor should one overlook the demonstrable and critical support that the fine arts and liberal education make to a community's culture. In the mass-market leisure industries, characterized by entertainment theme parks and enormous commodity consumption (Warpole, 1996), the university provides a rare institutional forum for artistic creativity and selfexpression which eventually find outlets in the community. As we note in the next section, an analysis of Canadian census statistics shows that fine arts graduates earn less than most other university graduates, and for some, this is evidence of the poor economic returns produced by the arts. In fact, the precise opposite is the case. While employment in artistic fields tends to be contract-based, and/or short-term - which likely accounts for the field's income levels - the overall economic contribution of arts and cultural activities is considerable. In 1992-93, these sectors employed 660,000 people 'directly and indirectly,' and contributed $\$ 23.8$ billion to Canada's gross domestic product (Turbide, 1995). Higher educational institutions thus help keep vibrant a community of writers, performers and producers that enrich the country's cultural and artistic life, as well as its tourist industry.

Liberal education also potentially offers perspective on contemporary problems in an era of rapid change, riven with uncertainty. Jansen and van der Veen (1996) contend that in the face of a technology-driven, ecologically disturbed, and economically polarized world, major social, political and ethical questions face every society, and the issue of the 
quality of leadership is especially pressing. "Who should rule us, who should manage us, how should we control them, are questions that have to be posed again and now on a much broader, global scale," (p. 125) and universities have a critical role to play in addressing such problems. Individuals, they argue, would benefit most from a form of schooling that eschews exclusively instrumentalist teaching on the one hand or instruction of ungrounded abstract concepts on the other. Education instead should "(re)integrate the teaching and learning of practical skills and knowledge that people need for daily living with the stimulation of questions and public debate about the future of society and the possible designs of individual and social life" (p. 129).

Of course, the mere provision of liberal arts courses is no guarantee that the intellectual and social goals outlined above will be achieved, nor would we argue that all students profit from their exposure to the liberal arts. There are, after all, " $D$ " students and other malingerers in all disciplines. Furthermore, arts courses that are delivered exclusively in extraordinarily large lectures by professors who fail to engage the attention, let alone the interest, of their students are unlikely to provide much pedagogical value. Courses whose assignments are based exclusively on multiple choice instead of research and writing requirements are more likely to serve the cause of rote learning than scholarly study. In other words, where the liberal arts are themselves taught in a mundane manner, stressing the consumption and uncritical reiteration of routine data, they probably contribute little to the cultivation of the student's intellect. Liberal arts courses and content are a necessary but not a sufficient basis for realizing the goals of liberal education. As Charles Anderson (1993) argues, universities need to attend critically and thoroughly to the means by which the ideals of liberal education can be achieved.

\section{THE ECONOMIC VALUE OF LIBERAL EDUCATION: LABOUR MARKET OUTCOMES, 1986 TO 1996}

We have attempted, thus far, to argue for the intellectual, social and cultural importance of liberal education. We recognize, however, that aspiring graduates are concerned, perhaps even preoccupied, with the 
occupational and income rewards of their university educations, and this section addresses this issue by drawing on micro-data files from the Canadian Census, 1986-1996. The data analysis explores the link between graduates' fields of study and their labour market outcomes. The focus of comparison is between university graduates who studied fine arts, humanities, and social sciences and those graduates who concentrated their studies in fields such as education, commerce, engineering, nursing and other health professions and math/physical sciences. ${ }^{1}$

Table 1 illustrates that enrolments in almost all fields of study ${ }^{2}$ between 1986 and 1996 remained relatively stable, and there are current indications that the demand for liberal education remains strong. ${ }^{3}$ In 1986 (nation-wide), $13.7 \%$ of all university graduates claimed humanities as their field of study; this decreased to $11.5 \%$ in 1996 . In $1986,17.3 \%$ of university graduates indicated the social sciences as their primary field of study and, by 1996, the proportion in the social sciences had increased to $18.1 \%$. The proportions studying in agriculture and biology decreased slightly over a decade while those concentrating their studies in commerce and engineering steadily increased. Other fields (e.g. math/physical sciences) showed fluctuations from 1986-1996. Table 4 also reveals gender segregation by field of study. Women still dominated in nursing and education, and comprised the majority of university graduates in fine arts, humanities, and the social sciences. In contrast, men were dominant in engineering, math and physical sciences and constituted the majority of graduates in commerce.

Table 2 provides unemployment rate information across fields of study for the most current census (1996) and illustrates that university graduates in both age cohorts experienced the lowest unemployment in comparison to high school non-completers, graduates and postsecondary certificate/diploma holders. Among university graduates in 25-29 age cohort, those in humanities had the highest unemployment rate $(9.4 \%)$, while those in nursing had the lowest rate $(4.4 \%)$. Social sciences $(7.9 \%)$, engineering $(7.4 \%)$, and math/physical sciences $(7.9 \%)$ graduates displayed similar unemployment rates. In contrast, fine arts graduates had a slightly lower rate $(6.5 \%)$ than the aforementioned non-liberal education graduates. Though there may have been a host of economic 


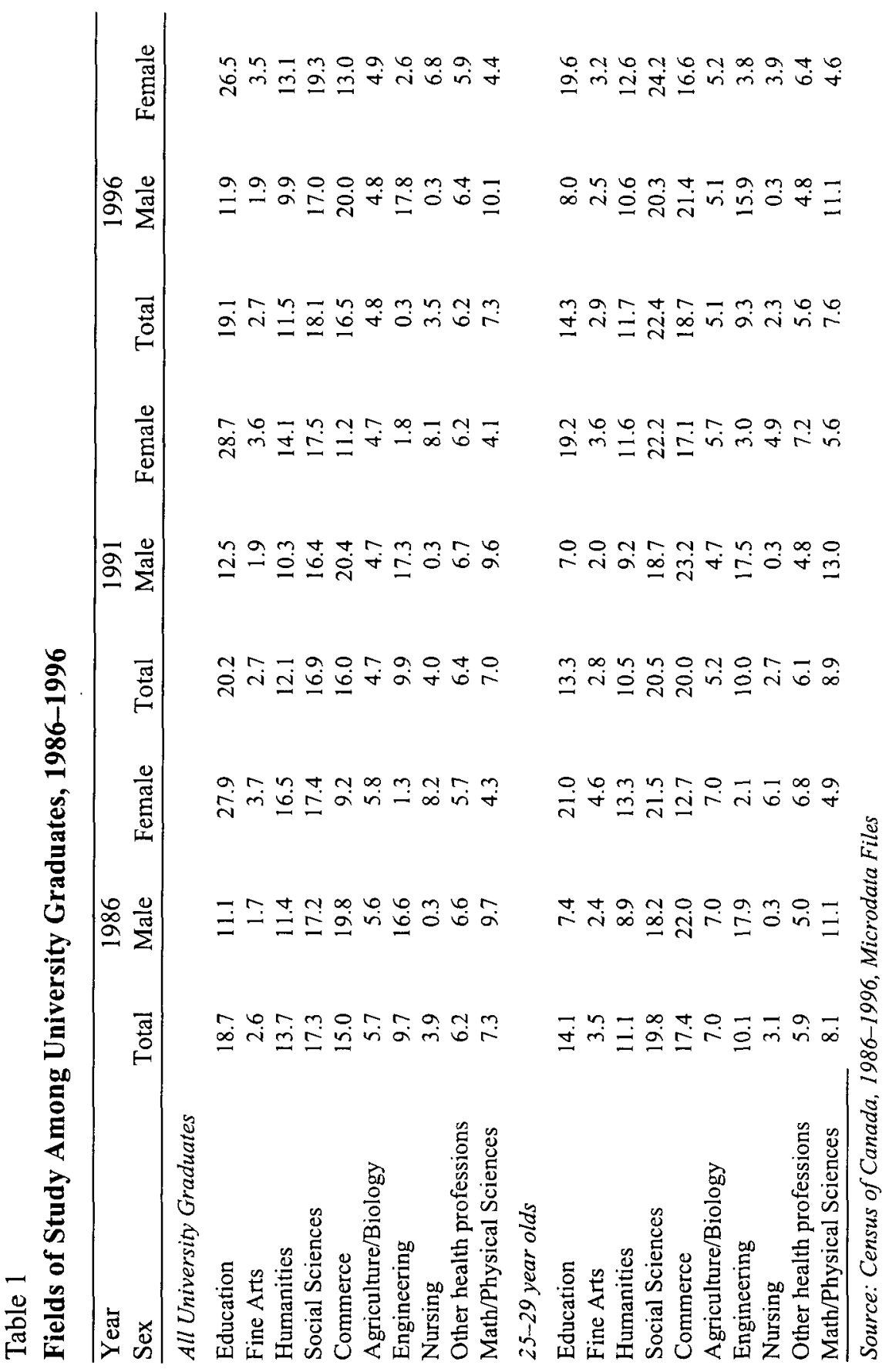


Table 2

Unemployment by Field of Study, 1996

\begin{tabular}{|c|c|c|c|c|c|c|}
\hline Sex & \multicolumn{3}{|c|}{$25-29$ year olds } & Total & \multicolumn{2}{|c|}{30 year olds and up } \\
\hline High school non-completers & 19.7 & 20.8 & 19.1 & 12.7 & 12.5 & 12.9 \\
\hline High school graduates & 11.5 & 12.2 & 10.9 & 7.8 & 7.8 & 7.8 \\
\hline $\begin{array}{l}\text { Postsecondary } \\
\text { certificate/diploma }\end{array}$ & 10.0 & 9.7 & 10.4 & 7.4 & 7.4 & 7.3 \\
\hline \multicolumn{7}{|l|}{ University Graduates } \\
\hline Education & 4.7 & 4.3 & 5.6 & 3.1 & 3.4 & 2.5 \\
\hline Fine Arts & 6.5 & 4.3 & 9.6 & 6.4 & 6.6 & 6.0 \\
\hline Humanities & 9.4 & 9.7 & 8.9 & 6.0 & 6.8 & 5.2 \\
\hline Social Sciences & 7.9 & 6.8 & 9.5 & 4.5 & 5.5 & 3.5 \\
\hline Commerce & 5.9 & 4.8 & 7.0 & 3.9 & 5.0 & 3.3 \\
\hline Agriculture/Biology & 6.9 & 7.0 & 6.7 & 4.8 & 6.0 & 3.7 \\
\hline Engineering & 7.4 & 8.5 & 7.1 & 5.2 & 10.0 & 4.6 \\
\hline Nursing & 4.4 & 4.3 & 7.1 & 3.6 & 3.7 & 1.8 \\
\hline Other health professions & 5.7 & 5.0 & 6.9 & 3.1 & 3.8 & 2.6 \\
\hline Math/Physical Sciences & 7.9 & 8.5 & 7.5 & 5.0 & 5.1 & 4.9 \\
\hline
\end{tabular}

Sources: Census of Canada, 1996, Micordata File 
and other factors that influenced the unemployment rates of graduates across different fields of study, the message conveyed by these findings is that there does not appear to be empirical justification for the belief that liberal fields of study lead graduates to higher levels of job insecurity than other fields. In examining the 30 and up age cohort, we found that the percentage gaps in unemployment across different fields of study actually narrowed, ranging from $3.1 \%$ for graduates in education and "other health professions," to $6.4 \%$ in fine arts. Graduates in the social sciences had lower unemployment rates $(4.5 \%)$ than engineering $(5.2 \%)$ and math/physical sciences $(5.0 \%)$ graduates. While we cannot conclude that graduates in liberal education fields had uniformly lower unemployment rates than other fields of study, the findings reported in Table 2 do not support the assumption that liberal education graduates experienced more negative labour market outcomes than non-liberal education graduates.

Table 3 shows that university graduates in 1996 were far more successful in entering either professional or managerial occupations whether they concentrated their studies in liberal arts or other fields of study. Thus, in examining those who were in the 25-29 year old cohort in 1996 , we found that the highest proportion of non-university graduates obtaining professional/managerial positions were postsecondary and diploma graduates $(26.2 \%)$, with gender variations being negligible for this group. In contrast, the range across all fields of study among university graduates in the same age cohort was $46.9 \%$ (Humanities) and $88.4 \%$ (other health professions). The magnitude of these differences was maintained when we inspected the 30 year and up category. Among liberal education graduates in the 25-29 age cohort, there was some variation in the proportion of professional/managerial ranging from $46.9 \%$ for humanities graduates to $56.3 \%$ for fine arts graduates. Gender variations within these fields of study were small except in the instance of fine arts where there was a $6.4 \%$ difference in favour of men. Generally speaking, however, occupational outcomes favoured graduates from non-liberal education fields for those in the 25-29 year old cohort, though there was a very strong variation ranging from $50.4 \%$ for commerce graduates to $88.4 \%$ for other health professions. With respect to 
Table 3

Proportion in Professional/Managerial Occupations by

Field of Study, 1996

25-29 year olds

\begin{tabular}{lccc}
\hline Sex & Total & Women & Men \\
\hline High school non-completers & 7.3 & 7.0 & 7.4 \\
High school graduates & 14.8 & 13.7 & 15.7 \\
Postsecondary certificate/diploma & 26.2 & 26.6 & 25.8 \\
University Graduates & & & \\
Education & 74.0 & 76.1 & 68.0 \\
Fine Arts & 56.3 & 53.7 & 60.1 \\
Humanities & 46.9 & 47.3 & 46.3 \\
Social Sciences & 49.0 & 48.5 & 49.6 \\
Commerce & 50.4 & 47.6 & 53.1 \\
Agriculture/Biology & 58.2 & 61.0 & 54.9 \\
Engineering & 76.1 & 71.5 & 77.4 \\
Nursing & 78.8 & 79.4 & 68.8 \\
Other health professions & 88.4 & 89.0 & 87.2 \\
Math/Physical Sciences & 71.1 & 66.7 & 73.2 \\
& & & \\
30 year olds and up & & & \\
\hline Sex & Total & Women & Men \\
\hline High school non-completers & 10.7 & 8.8 & 12.0 \\
High school graduates & 19.2 & 14.8 & 24.0 \\
Postsecondary certificate/diploma & 32.7 & 34.0 & 31.6 \\
University Graduates & & & \\
Education & 80.9 & 79.1 & 84.4 \\
Fine Arts & 71.1 & 68.3 & 75.9 \\
Humanities & 67.7 & 63.0 & 72.9 \\
Social Sciences & 68.7 & 65.4 & 71.8 \\
Commerce & 63.0 & 52.3 & 68.7 \\
Agriculture/Biology & 63.0 & 63.1 & 63.0 \\
Engineering & 77.8 & 67.7 & 78.9 \\
Nursing & 83.8 & 84.0 & 79.5 \\
Other health professions & 90.0 & 85.9 & 93.1 \\
Math/Physical Sciences & 77.8 & 70.2 & 80.5 \\
\hline Source: Census of Canada 1996, Microdata File & & \\
\hline
\end{tabular}

The Canadian Journal of Higher Education

Volume XXXI, No. 2, 2001 
university graduates in the 30 and up cohort, graduates in all fields appear to have improved their employment prospects and increased their representation in professional/managerial occupations. This improvement appeared especially strong for those in liberal education fields. Thus, fine arts graduates increased their profile by $14.8 \%$ to $71.1 \%$; humanities graduates enhanced their representation by $20.8 \%$, to $67.7 \%$ and social science graduates showed similar gains in representation, increasing from $49.0 \%$ to $68.7 \%$.

When we turned to an analysis of income by field of study in 1996, we found a strong correspondence between income and occupational attainment findings. Thus, the employment incomes of high school noncompleters $(\$ 11,302)$, high school graduates $(\$ 15,827)$ and postsecondary certificate/diploma holders $(\$ 18,652)$, aged $25-29$, were generally and consistently lower than for all university graduates whatever their field of study, with some notable exceptions. High school graduates earned more than fine arts graduates $(\$ 13,017)$ and postsecondary certificate/diploma graduates earned more than fine arts, humanities $(\$ 16,451)$ and agriculture/biology graduates $(\$ 17,159)$. It is also important to note the gender differences in earnings with these differences being particularly pronounced among those obtaining lower levels of education. For example, among high school non-completers, men earned more than double $(\$ 15,124)$ the wages of women $(\$ 6,619)$; these gender differences were also quite significant among high school graduates and postsecondary certificate/diploma graduates. Among university graduates, the only field in which women's earnings exceeded that of men was nursing. The previous table also shows that the proportion of women in nursing classified as professional/managerial was higher than that of men. Though earnings differences in favour of men were insignificant in some fields of study (e.g., humanities, agriculture/biology) most other fields, be they liberal or professional, showed employment income differences that favoured men over women. These advantages were significantly stronger among graduates who were in the 30 year old and up age cohort. Indeed, the salary advantage of women in nursing reverses for this age group, with men earning substantially higher incomes than women. These gender differences are manifested across all fields of study. 
Table 4

\section{Income by Field of Study, 1996}

\section{5-29 year olds}

\begin{tabular}{lcrc}
\hline Sex & Total & Women & Men \\
\hline High school non-completers & 11,302 & 6,619 & 15,124 \\
High school graduates & 15,827 & 11,862 & 19,689 \\
Postsecondary certificate/diploma & 18,652 & 15,220 & 22,595 \\
University Graduates & & & \\
Education & 20,692 & 20,446 & 21,408 \\
Fine Arts & 13,017 & 11,966 & 14,618 \\
Humanities & 16,451 & 16,207 & 16,799 \\
Social Sciences & 19,248 & 17,745 & 21,385 \\
Commerce & 25,165 & 24,614 & 25,676 \\
Agriculture/Biology & 17,159 & 17,000 & 17,355 \\
Engineering & 25,098 & 19,422 & 26,715 \\
Nursing & 23,621 & 23,895 & 19,128 \\
Other health professions & 22,925 & 23,483 & 22,027 \\
Math/Physical Sciences & 24,021 & 22,399 & 24,822
\end{tabular}

30 year olds and up

\begin{tabular}{lrrr}
\hline Sex & Total & Women & Men \\
\hline High school non-completers & 9,345 & 5,277 & 14,013 \\
High school graduates & 17,998 & 12,609 & 25,324 \\
Postsecondary certificate/diploma & 22,204 & 16,040 & 28,178 \\
University Graduates & & & \\
Education & 29,954 & 26,155 & 37,779 \\
Fine Arts & 17,761 & 15,488 & 21,898 \\
Humanities & 25,940 & 22,025 & 30,667 \\
Social Sciences & 32,981 & 25,797 & 39,996 \\
Commerce & 39,166 & 29,126 & 44,747 \\
Agriculture/Biology & 27,505 & 21,020 & 33,343 \\
Engineering & 39,674 & 23,084 & 41,505 \\
Nursing & 26,763 & 26,511 & 32,264 \\
Other health professions & 31,910 & 27,118 & 35,685 \\
Math/Physical Sciences & 38,314 & 28,457 & 42,138
\end{tabular}

Source: Census of Canada 1996, Microdata File (1995 constant dollar) 
Significantly, however, as they aged, women in the humanities and social sciences improved their incomes at a more rapid pace than did women in commerce and engineering. Those over 30 in the humanities and social sciences raised their incomes by $35.9 \%$ and $45 \%$ respectively compared to $18.6 \%$ for female engineers and $20.5 \%$ for female commerce graduates. Similar patterns occurred for graduates as a whole. Graduates over 30 from the social sciences improved their incomes by $71.3 \%$ and those from the humanities by $57.6 \%$. Commerce graduates saw their incomes rise by $55.6 \%$ and engineers by $58 \%$. Thus while those in the male-dominated fields, especially commerce, the professions and the sciences earned higher incomes than those in the humanities and social sciences (Table 4), the income gaps between these fields closed as graduates got older. Those trained in the liberal arts reaped significant economic benefits from their university training, particularly in the longer term.

Overall, these findings document that liberal arts graduates have done relatively well in the world of employment. As Livingstone (1999) and Anisef et al.(1996) demonstrate, some unquestionably have faced under-employment in an uncertain economy, but this experience has not been confined to the liberal arts fields. Historically, the occupational fate of engineers and other professionals has fluctuated with market conditions, which are largely unpredictable (Advisory Committee, 1974; Bouchard, 1998; Labour Market Development, 1981). Marginalizing liberal education within the university curricula in favour of more "applied" subjects will not only have enormous social, intellectual and cultural costs, but such a strategy is unlikely to generate more economic security for individuals or for the community as a whole.

\section{CONCLUSION}

In recent years, globalization, privatization, deficit-cutting, and the supposed needs of a "knowledge-based" market economy have driven governments to reshape their approaches to higher education. Funding now privileges the market-oriented, high-technology fields of study, in which students, too, are showing growing interest. But such policies and 
choices are based on the belief that liberal education has little investment value for the individual and society.

We have challenged this assumption and the misguidedness of the policies on which it is based. Overall, liberal arts graduates have succeeded in the world of employment, though the future for students in these and others fields, as always, cannot be predicted with certainty. We contend that liberal education is the core of higher learning - in good economic times and bad - and in its effort to prepare people for employment, the university must not be permitted to raze its own intellectual and cultural foundations. Liberal education has a vital place in arts and science courses, and in innovatively designed professional and vocational programs. In any event, the liberal arts are not static; they continue to be reformed, but less in response to ephemeral market trends than on the basis of evolving intellectual currents. As employers themselves have periodically asserted, by broadening the knowledge base of employees, liberal education can enhance the abilities of graduates in applied fields and enrich society as a whole. As they develop programs and allocate resources, policy makers would be well advised to heed this advice. So, too, would students as they plan their academic and occupational careers.

\section{Notes}

1 Other researchers have recently employed census micro data files to analyse the employability of university graduates in various fields of study and have also examined trends with respect to employment outcomes (see Allen 1998; Guppy \& Davies, 1998; Institute for Social Research, 1998; Lin, 1999; Paju, 1997). All of these studies demonstrate the economic value of a university education (individually and socially), including of the liberal arts. Our paper extends the previous analyses by including the most recent (1996) census. It also consistently employs specific age cohorts across the 1971-1996 censuses to provide a picture of life course changes by educational level and type, with respect to different labour market outcomes. Finally, the status of visible minorities from the 1986, 1991 and 1996 censuses is introduced to provide relevant information regarding their participation in different fields of study. 
2 Field of study was not measured prior to the 1986 census.

3 According to the Ontario Universities Application Centre (2000), the percentage of university applicants selecting Arts as their first university program choice rose by 6 percent in February 2000 compared to February 1999. By contrast, the percentage of those whose first choice was business, and engineering and science fell from the previous year by $0.6 \%$ and $1.7 \%$, respectively.

\section{References}

Advisory Committee on Academic Planning. (1974). Chemical engineering, report no. 11, A-7. In P. Axelrod (1982), Scholars and dollars: Politics, economics, and the universities of Ontario, 1945-1980, (pp. 45-47). Toronto, ON: University of Toronto Press..

Allen, R.C. (1998). The employability of university graduates in the humanities, social sciences and education: Recent statistical evidence. Unpublished paper.

Anderson, C.W. (1993). Prescribing the life of the mind: An essay on the purpose of the university, the aims of liberal education, the competence of citizens, and the cultivation of practical reason. Madison, WI: The University of Wisconsin Press.

Anisef, P., Ashbury, F., Bischoping, K., \& Lin, Z. (1996). Postsecondary education and underemployment in a longitudinal study of Ontario babyboomers. Higher Education Policy, 9(2), 159-174.

Anisef, P., Axelrod, P., \& Lin, Z. (1999). Universities, liberal education and the labour market: Trends and prospects. Paper presented to Trade Unions and Training: from Global Demands to Local Action, Université Laval, May 29. Sponsored by the Centre for Research on Work and Society, York University.

Armstrong, A., \& Casement, C. (1998). The child and the machine: Why computers may put our children's education at risk. Toronto, ON: Key Porter Books.

Arthurs, H.W. (1998). The political economy of Canadian legal education. Journal of Law and Society, 25(1), 14-32.

Axelrod, P. (1998). Challenges to liberal education in an age of uncertainty. Historical Studies in Education, 10(1/2), 1-19.

Axelrod, P. (1990). Making a middle class: Student life in English Canada during the thirties. Montreal, QC/Kingtson, ON. McGill-Queen's University Press. 
Axelrod, P. (1982). Scholars and dollars: Politics, economics and the universities of Ontario, 1945-1980. Toronto, ON: University of Toronto Press.

Bledstein, B. (1976). The culture of professionalism: The middle class and the development of higher education in America. New York, NY: W.W. Norton and Company.

Bond, A. (1982). The arts that liberate. In J.M. Watson \& R.P. Stevens, (Eds.), Pioneers and pallbearers: Perspectives on liberal education, (pp. 127-145). Macon, GA: Mercer University

Bouchard, P. (1998). Training and work: Some myths about human capital. In S. Scott, B. Spencer, \& A.M. Thomas, (Eds.), Learning for life: Canadian readings in Adult Education. Toronto, $\mathrm{ON}$ : Thompson Educational Publishers.

Canadian Broadcasting Corporation. (1999). The education debates. (David Cayley, ed.). Toronto, ON: Canadian Broadcasting Corporation, January.

Census of Canada, Microdata, 1971-1996.

College-University Consortium Council. (1998). Report of the collegeuniversity consortium council, 1996-1998. Submitted to the Minister of Education and Training. Toronto, ON: Council of Ontario Universities.

Consultative Group on Research and Education in Law. (1983). Law and Learning. Report to the Social Sciences and Humanities Research Council of Canada.

Employment and Immigration Canada. (1981). Labour market development in the 1980s. A report of the task force on labour market development, prepared for the Minister of Employment and Immigration. Ottawa, ON: Employment and Immigration Canada,45-7.

Frank, T. (1997). What do employers want? University Affairs, (May), 8-10.

Freedman, J.O. (1996). Idealism and liberal education. Ann Arbor. MI: University of Michigan Press.

Glyer, D., \& Weeks, D.L. (1998). The liberal arts in higher education: Challenging assumptions, exploring possibilities. Lanham, MD: University Press of America.

Godsoe, P.C. (1996). Universities must excel despite less funding. Canadian Speeches, 10(April), 40-45.

Guppy, N., \& Davies, S. (1998). Education in Canada: Recent trends and future. Ottawa, ON: Minister of Industry.

Hersh, R.H. (1997). Intentions and perceptions: A national survey of public attitudes towards liberal arts education. Change, 29(2), (March-April), 16-23.

Ibbitson, J. (2000). Universities and colleges to enjoy big expansion. Globe and Mail, Feb. 23. 
Institute for Social Research, York University. (1998). Arts graduates get jobs. Student experience study, bulletin 30. March 15.

Jansen, T., \& van der Veen. R. (1996). Adult education in the light of the risk society. In P. Raggat, R. Edwards, \& N. Small (Eds), The learning society: Challenges and trends, (pp. 122-135). London, UK: Routledge and the Open University.

Kimball, B.A. (1995). Orators and philosophers: A history of the idea of liberal education. New York, NY: College Education Examination Board.

Lin, Z. (1999). How do university graduates cope with risk? Exploring the relationship between education and work. An analysis of the 1992 National Graduate Survey. Unpublished Ph.D. dissertation, York University.

Lipman-Blumen, J. (1995). The creative tension between liberal arts and specialization. Liberal Education, 81(1), (Spring), 17-25.

Little, D. (1998). Multiple goals in the liberal arts: A reply to Joseph Wagner. Interchange, 29(3), 345-350.

Livingstone, D.W. (1999). The education-jobs gap: Underemployment or economic democracy. Toronto, ON. Garamond Press.

Mallan, C., \& Rushowy, K. (2000). University funding to be tied to jobs record. Toronto Star, March 15.

McPhedran, N.T. (1993). Canadian medical schools: Two centuries of medical history, 1822 - 1992. Montreal, QC: Harvest House.

McPherson, M.S., \& Schapiro, M.O. (1999). Economic challenges for liberal arts colleges. Daedalus, 128(1), (Winter), 47-75.

Nesteruk, J. (1999). Business teaching and liberal learning. Liberal Education, 85(2), (Spring), 56-59.

Nuland, S.B. (1999). The uncertain art: The medical school and the university. The American Scholar, 68(1), (Winter), 121-124.

Ontario Universities' Application Centre. (2000). www.ouac.on.ca.

Paju, M. (1997). The class of 1990 revisited: Report of the 1995 follow-up survey of 1990 graduates. Education Quarterly Review 4(4), 9-29.

Rappleye, W.L. (1932). Final report of the commission on medical education. New York, NY: Office of the Director of the Study.

Rothblatt, S. (1993). The limbs of Osiris: Liberal education in the Englishspeaking world. In S. Rothblatt \& B. Wittrock (Eds.), The European and American university since 1800: Historical and sociological essays, (pp. 19-73). Cambridge, UK: Cambridge University Press. 
Rubenson, K. (1997). What is driving the policy formation on education and training? WRNET 3rd Annual Conference: What skills matter in the economy? February 26-27.

Schneider, C. \& Shoenberg, R. (1998). Contemporary understandings of liberal education. Liberal Education, (Spring), 32-37.

Schmidt, H.K. (1990). Innovative and conventional curricula compared: What can be said about their effects? In Z.M. Nooman, H.G. Schmidt, \& E.S. Ezzat, (Eds.), Innovation in medical education: An evaluation of its present status, (pp. 1-7). New York, NY: Springer Publishing.

Simpson, D.J., \& Jackson, M.J.B. (1997). Educational reform: A Deweyan perspective. New York, NY: Garland Publishing, Inc.

Slaughter S., \& Leslie, L.L. (1997). Academic capitalism: Policies and the entrepreneurial university. Baltimore. MD: The Johns Hopkins University Press.

Tagg, J. (1998). The decline of the knowledge factory: Why our colleges must change. World and I, 6(1).

Tapscott, D. (1999). Education becomes a lifelong process. National Post, July 5 , p. C3.

The Association of American Colleges and Universities. (1999). Statement on liberal learning. Liberal Education. 85(2), 6-7.

Tudiver, N. (1999). Universities for sale: Resisting corporate control over Canadian higher education. Toronto, ON: James Lorimer and Company.

Turbide, D. (1995). Assessing the damage. Maclean's. March 20, 78.

Useem, M. (1995). Corporate restructuring and liberal learning. Liberal Education, Winter, 18-23.

Vanderleest, J. (1996). The purpose and content of liberal education. In C. Storm (Ed.), Liberal education and the small university in Canada, (pp. 3-17). Montreal, QC and Kingston, ON: McGill-Queen's University Press.

van der Zee, H. (1996). The learning society. In P. Raggat, R.Edwards, \& N. Small (Eds.), The learning society: Challenges and trends, (pp. 162-183), London, UK: Routledge and the Open University.

Wagner, J. (1998). A subtle tyranny: Rediscovering the purpose of the liberal arts. Interchange, 29(3), 327-344.

Warpole, K. (1996). The age of leisure. In P. Raggat, R. Edwards, \& N. Small (Eds.), The learning society: Challenges and trends, (pp. 112-121), London, UK: Routledge and the Open University.

Wasylenki, D.A., Cohen, C.A., \& McRobb, B.R. (1997). Creating community agency placements for undergraduate medical education: A program description. Canadian Medical Association Journal, 156(3), 379-383. 
Wilson, H.T. (1999). No ivory tower: The university under siege. Richmond, ON: Voyageur Publishing.

Woodward, C.A. (1990). Monitoring an innovation in medical education: The McMaster experience. In Z.M. Nooman, H.G. Schmidt, \& E.S. Ezzat (Eds.), Innovation in medical education: An evaluation of its present status, (27-39). New York, NY: Springer Publishing Company. 